\title{
Biological monitoring of cyclophosphamide and ifosfamide in urine of hospital personnel occupationally exposed to cytostatic drugs
}

\author{
Angela S Ensslin, Yvonne Stoll, Angelika Pethran, Andreas Pfaller, Horst Römmelt, \\ Günter Fruhmann
}

\begin{abstract}
The occupational exposure of 21 nurses and pharmacy personnel from eight hospitals to cyclophosphamide and ifosfamide was determined by quantifying the amount of the drugs handled and by measuring the urinary excretion of the unmetabolised substances. Preparing antineoplastic drugs for intravenous treatment was the major task of all study participants. Twenty four hour urine was collected on days when cyclophosphamide and/or ifosfamide were mixed, on average $3900 \mathrm{mg}$ cyclophosphamide and/or $5900 \mathrm{mg}$ ifosfamide. The analyses were performed by gas chromatography with electron capture, detection limit $2 \cdot 5 \mu \mathrm{g} / 24$ hour urine. Despite standard safety precautions, including a vertical laminar air flow safety cabinet and gloves, cyclophosphamide was detected in 12 of 31 and ifosfamide in four of 21 urine samples on days when the drugs were handled. Excretion of cyclophosphamide ranged from 3.5 to $38 \mu \mathrm{g} / 24 \mathrm{~h}$ (mean $11.4 \mu \mathrm{g} / 24 \mathrm{~h}$ ) urine, ifosfamide from 5 to $12.7 \mu \mathrm{g} / 24 \mathrm{~h}$ (mean $9 \mu \mathrm{g} / 24 \mathrm{~h}$ ) urine. Based on an excretion rate of $11 \cdot 3 \%$ unmetabolised cyclophosphamide, the average amount excreted corresponded to an uptake of $101 \mu \mathrm{g}$ cyclophosphamide. For ifosfamide the mean quantity incorporated was $20 \mu \mathrm{g}$ assuming that $45 \%$ of the drug was excreted. Pertaining to the doses handled, the uptake of cyclophosphamide and ifosfamide was estimated to be approximately $0.0025 \%$ and $0.0004 \%$ respectively. Despite time-consuming purification procedures, gas chromatographic analysis is a suitable method for monitoring personnel occupationally exposed to cyclophosphamide and ifosfamide and is a major contribution to the evaluation of potential health risks of exposed personnel.
\end{abstract}

(Occup Environ Med 1994;51:229-233)

The amount of antineoplastic drugs employed for treatment of malignant diseases is constantly increasing. Diverse chemical substances capable of inhibiting tumour growth are known. Many chemotherapeutic agents are carcinogenic in animals-for example, dacarbazine and cyclophosphamide. ${ }^{1}$ Of these, cyclophosphamide is judged to be a human carcinogen. ${ }^{1-5}$ Also, it is known to have mutagenic and teratogenic effects.

It is of increasing concern that professional personnel involved in the preparation and administration of antineoplastic drugs are occupationally exposed to these substances. Various safety measures have been introduced in the past and handling practices have been improved, although these are not generally standard. ${ }^{6}$

Recently, in many hospitals the task of preparing antineoplastic drugs has been restricted to a separate room usually installed in the hospital pharmacy. Here, specially trained personnel (nurses, medical or pharmacy technicians, pharmacists) are responsible for the preparation of antineoplastic drugs for all hospital wards. Consequently, these workers face a cumulative exposure.

The purpose of this study was to quantify the exposure by measuring the excretion of cyclophosphamide and ifosfamide in the urine of employees regularly handling these agents in hospital pharmacies. Emphasis was given to the exact amount of antineoplastic drugs mixed. Cyclophosphamide and ifosfamide were chosen as a substantial proportion of both drugs is excreted in urine unmetabolised. ${ }^{7-9}$ Furthermore, these substances are considered representative of commonly used antineoplastic drugs and their pharmacokinetic properties are well studied. $^{810}$

\section{Subjects and methods}

The investigation was carried out on 21 workers (17 women) comprising nurses, pharmacy technicians, and pharmacists at eight hospitals with 200-2000 beds in and around Munich, most of them affiliated to universities. Mixing antineoplastic drugs was a major feature of their job description. All the currently employed pharmacy personnel of the institutions mentioned involved in the preparation of cytostatic drugs participated in the study. The duration of occupational exposure to antineoplastic agents varied between two months and six years (mean 23 months). A detailed written questionnaire was given to each participant and information was provided on personal data including age, smoking habits, current medication, duration of exposure to cytostatic drugs, exact working conditions, date and time of urine collection, and number and dosage of 
all drug preparations on days when urine was collected including two days before urine collection as well as accidental spills or glove tears.

The mean age was 36 (range 26-55) years. Only one of the participants smoked. One pharmacist reported regular intake of analgesics because of rheumatoid arthritis, another was taking $\beta$ blockers for hypertension, and six women took oral contraceptives. The physical examination of 16 study participants revealed pathological findings not related to the occupational exposure-for example, hypertension and scoliosis. Medical histories were unremarkable; in particular no neoplastic diseases or spontaneous abortions were reported. Healthy children were born to a female pharmacist (personnel No 19) and a male pharmacist (personnel No 17). Blood tests were performed including a blood cell count and differentiation, sedimentation rate, creatinine, aspartate aminotransferase, alanine aminotransferase, glutamyltransferase, and urine analysis. Laboratory findings most likely due to infectious diseases were seenfor example, increased blood sedimentation rate in three participants, five persons with relative lymphocytosis, and an increased percentage of monocytes in two cases $(6 \%, 8 \%)$. Urinary contamination by bacteria was a frequent finding. Slight anaemia was seen in three young female participants and alanine aminotransferase was slightly raised in two persons (personnel No 13: $29 \mathrm{U} / \mathrm{l}$, personnel No 15: $25 \mathrm{U} / 1$ ).

The participants were requested to collect urine over a period of 24 hours on days when either cyclophosphamide, ifosfamide, or both drugs were handled. Collection of urine was supervised by us, beginning with the first handling of antineoplastic drugs in the morning. The samples were frozen at $-20^{\circ} \mathrm{C}$ immediately after collection and analysed after 96 (SD 38) days. Stability of cyclophosphamide and ifosfamide under these conditions has been reported by Sessink et al. ${ }^{11}$ Participants collected one to five urine samples.

The detection of cyclophosphamide and ifosfamide was performed by gas chromatography with electron capture. Before gas chromatographic analysis $200 \mathrm{ml}$ of urine was purified as described by Evelo et $a l^{12}$ and
Hirst et al. ${ }^{13}$ The final sample was dissolved in $100 \mu 1$ isooctane.

\section{GAS CHROMATOGRAPHIC ANALYSIS}

Each sample $(1 \mu \mathrm{l})$ was injected into a Shimadzu gas chromatograph. An OV-1 column was used with a nitrogen flow of $27 \mathrm{ml} / \mathrm{min}$. The injection temperature was $300^{\circ} \mathrm{C}$. The initial temperature of $190^{\circ} \mathrm{C}$ was increased after two minutes by $8 \% \mathrm{~min}$ to $230^{\circ} \mathrm{C}$ for 10 minutes and then raised by $10^{\circ} / \mathrm{min}$ to $280^{\circ} \mathrm{C}$ for 25 minutes to clean the column. The retention times of trifluoracetic acid derivates from cyclophosphamide and ifosfamide were 8.7 and 7.4 minutes respectively. The detection limit for cyclophosphamide and ifosfamide was $2.5 \mu \mathrm{g} / 24 \mathrm{~h}$ urine.

As internal standards $10 \mu \mathrm{g}$ cyclophosphamide or ifosfamide were added to $200 \mathrm{ml}$ urine unless both drugs were handled on the day of urine collection. The recovery rates for cyclophosphamide and ifosfamide were determined by spiking urine from an unexposed person with $200 \mu \mathrm{g}$ cyclophosphamide or ifosfamide per $200 \mathrm{ml}$ urine. The extraction recovery was $40.4(2.74) \%(n=4)$ and 80.6 $(7 \cdot 66) \%(n=4)$, respectively. The calculation of the final urinary excretion of cyclophosphamide and ifosfamide was based on these recovery rates. Urinary creatinine was determined in each sample.

Due to impurities in the urine 10 of 41 cyclophosphamide samples and one of 22 ifosfamide samples could not be analysed.

The percentage of unmetabolised cyclophosphamide and ifosfamide excreted was determined by analysing 24 hour urine of patients treated intravenously with either drug (11.3\% and $45 \%$, respectively).

\section{STATISTICS}

The statistical calculations were performed with SPSS software comprising regression analysis and Mann-Whitney tests. Results are presented as means (SD).

\section{Results}

The working conditions differed slightly among the hospitals with respect to glove thickness, the use of protective clothing, frequency of waste disposal, and daily work

Table 1 Working conditions and safety measures

\begin{tabular}{|c|c|c|c|c|c|c|}
\hline Hospital & $\begin{array}{l}\text { Nursel } \\
\text { pharmacy } \\
\text { personnel }\end{array}$ & $\begin{array}{l}\text { Laminar air } \\
\text { flow cabinet }\end{array}$ & Gloves & Protective clothing & $\begin{array}{l}\text { Waste } \\
\text { disposal }\end{array}$ & $\begin{array}{l}\text { Daily work } \\
\text { loadlperson } \\
\text { (h) }\end{array}$ \\
\hline $\begin{array}{l}\text { A } \\
\text { B } \\
\text { C } \\
\text { D }\end{array}$ & $\begin{array}{l}1-4 \\
5 \\
6-9 \\
10\end{array}$ & $\begin{array}{l}\text { Yes } \\
\text { Yes } \\
\text { Yes } \\
\text { Yes }\end{array}$ & $\begin{array}{l}\text { Latex }^{\star} \\
\text { Latex } \\
\text { latext } \\
\text { Latex }{ }^{\star} \text { over } \\
\text { polyethylene }\end{array}$ & $\begin{array}{l}\text { Cotton gown } \\
\frac{D}{-}\end{array}$ & $\begin{array}{l}\text { Pactosafe } \\
2 \times \text { week } \\
\text { Daily } \\
\text { Daily }\end{array}$ & $\begin{array}{l}2 \\
3 \\
\text { Variable } \\
5\end{array}$ \\
\hline $\mathbf{E}$ & 11,12 & Yes & Latex ${ }^{\star}$ & $\begin{array}{l}\text { Disposable gown, sleeve } \\
\text { protector }\end{array}$ & 2-3 $\times$ week & 5 \\
\hline $\mathbf{F}$ & $13-15$ & Yes & Latex $^{\star}$ & $\begin{array}{l}\text { Disposable gown, sleeve } \\
\text { protector }\end{array}$ & $2-3 \times$ week & 5 \\
\hline $\begin{array}{l}\mathrm{G} \\
\mathbf{H}\end{array}$ & $\begin{array}{l}16-20 \\
21\end{array}$ & $\begin{array}{l}\text { Yes } \\
\text { Yes }\end{array}$ & $\begin{array}{l}\text { Latex* } \\
\text { Latex } \neq\end{array}$ & $\begin{array}{l}\text { Cotton gown } \\
\text { Disposable gown }\end{array}$ & $\begin{array}{l}\text { Pactosafe } \\
2 \times \text { week }\end{array}$ & $\begin{array}{l}4 \\
1-3\end{array}$ \\
\hline
\end{tabular}

*Thickness $0.15-0.3 \mathrm{~mm}$; thickness $0.22-0.45 \mathrm{~mm}$; fthickness $0.3-0.35 \mathrm{~mm}$. 
Table 2 Urinary cyclophosphamide and ifosfamide excretion of hospital personnel in relation to the dosage handled and number of preparations

\begin{tabular}{|c|c|c|c|c|c|c|c|c|}
\hline $\begin{array}{l}\text { Nursel } \\
\text { pharmacy } \\
\text { personnel }\end{array}$ & $\begin{array}{l}\text { Number } \\
\text { of } C P \\
\text { preparations }\end{array}$ & $\begin{array}{l}\text { Dose of } \\
C P \text { handled } \\
(m g)\end{array}$ & $\begin{array}{l}C P \\
(\mu g / 24 h \\
\text { urine })\end{array}$ & $\begin{array}{l}C P \\
\text { ( } \mu g / g \\
\text { creatinine) }\end{array}$ & $\begin{array}{l}\text { Number } \\
\text { of IF } \\
\text { preparations }\end{array}$ & $\begin{array}{l}\text { Dosage of } \\
\text { IF handled } \\
\text { (mg) }\end{array}$ & $\begin{array}{l}\text { IF } \\
(\mu g / 24 h \\
\text { urine })\end{array}$ & $\begin{array}{l}\text { IF }(\mu g / g \\
\text { creatinine) }\end{array}$ \\
\hline $\begin{array}{r}1 \\
2 \\
3 \\
4 \\
4 \\
6 \\
8 \\
9 \\
12 \\
14 \\
15 \\
18 \\
21 \\
21\end{array}$ & $\begin{array}{r}9 \\
4 \\
15 \\
11 \\
11 \\
2 \\
0 \\
3 \\
4 \\
1 \\
2 \\
11 \\
2 \\
3\end{array}$ & $\begin{array}{r}8580 \\
3560 \\
12720 \\
9218 \\
8620 \\
1000 \\
0 \\
2740 \\
3076 \\
1000 \\
3480 \\
8350 \\
1700 \\
2500\end{array}$ & $\begin{array}{c}4 \cdot 82 \\
16 \cdot 36 \\
3 \cdot 74 \\
38 \cdot 23 \\
10 \cdot 00 \\
7 \cdot 25 \\
\mathrm{NA} \\
\mathrm{ND} \\
8 \cdot 55 \\
6 \cdot 26 \\
3 \cdot 48 \\
14 \cdot 90 \\
10 \cdot 12 \\
13 \cdot 16\end{array}$ & $\begin{array}{c}4.57 \\
7 \cdot 45 \\
4.08 \\
7.89 \\
8 \cdot 05 \\
9 \cdot 88 \\
\text { NA } \\
\text { ND } \\
5 \cdot 99 \\
4.64 \\
1.52 \\
9 \cdot 39 \\
7 \cdot 81 \\
10.99\end{array}$ & $\begin{array}{l}0 \\
1 \\
4 \\
6 \\
4 \\
0 \\
1 \\
2 \\
2 \\
1 \\
2 \\
0 \\
0 \\
0\end{array}$ & $\begin{array}{r}0 \\
5160 \\
17290 \\
11360 \\
10820 \\
0 \\
2710 \\
4540 \\
3700 \\
2340 \\
6000 \\
0 \\
0 \\
0\end{array}$ & $\begin{array}{l}\text { ND } \\
\text { ND } \\
5 \cdot 05 \\
\text { ND } \\
12 \cdot 74 \\
\text { NA } \\
8 \cdot 40 \\
9 \cdot 88 \\
\text { ND } \\
\text { ND } \\
\text { ND } \\
\text { NA } \\
\text { NA } \\
\text { NA }\end{array}$ & $\begin{array}{l}\text { ND } \\
\text { ND } \\
5 \cdot 49 \\
\text { ND } \\
10 \cdot 26 \\
\text { NA } \\
7 \cdot 64 \\
15 \cdot 50 \\
\text { ND } \\
\text { ND } \\
\text { ND } \\
\text { NA } \\
\text { NA } \\
\text { NA }\end{array}$ \\
\hline
\end{tabular}

$\mathrm{CP}=$ cyclophosphamide; $\mathrm{IF}=$ ifosfamide; $\mathrm{NA}=$ not analysed; $\mathrm{ND}=$ not detected.

load (table 1). One accidental spill of $1 \mathrm{ml}$ cyclophosphamide was reported by a nurse.

For 41 samples cyclophosphamide handling on the day of urine collection was $>750 \mathrm{mg}$ (mean 3877 (3053) mg; maximum $12720 \mathrm{mg}$ ). In 12 out of 31 analysed samples (mean cyclophosphamide handling 4321 (3277) $\mathrm{mg}$ ) cyclophosphamide was above the detection limit of $2.5 \mu \mathrm{g} / 24 \mathrm{~h}$ urine at a concentration of $3.5-38 \mu \mathrm{g} / 24 \mathrm{~h}$ urine or $1.5-10.9 \mu \mathrm{g} / \mathrm{g}$ creatinine (mean $11.4 \mu \mathrm{g} / 24 \mathrm{~h}$ urine, $6.8 \mu \mathrm{g} / \mathrm{g}$ creatinine).

Cyclophosphamide could not be detected in three additional urine samples when hospital personnel had mixed cyclophosphamide only one or two days before collection of urine. The participants collected 22 samples on days when ifosfamide was manipulated (mean 5859 (4260) mg; maximum 17290 $\mathrm{mg}$ ). Ifosfamide excretion of $5-12.7 \mu \mathrm{g} / 24 \mathrm{~h}$ urine or $5.5-15.5 \mu \mathrm{g} / \mathrm{g}$ creatinine (mean $9 \mu \mathrm{g} / 24 \mathrm{~h}$ urine, $9.7 \mu \mathrm{g} / \mathrm{g}$ creatinine) was found in four of 21 analysed samples (mean ifosfamide handling 5734 (4323) $\mathrm{mg}$ ) but was not measurable in three additional urine samples collected one to two days after handling ifosfamide.

Table 2 depicts the individual results of the gas chromatographic analysis and the amount of cyclophosphamide and ifosfamide handled on the day of urine collection. No correlation was found between the total dose or number of cyclophosphamide or ifosfamide preparations handled on the day of exposure or with respect to the two days before the day of urine collection. Cyclophosphamide was detected in one urine sample of a male participant; four samples from male hospital personnel were negative for cyclophosphamide and two were negative for ifosfamide. There was no correlation with the age of the participants or the duration of occupational exposure to antineoplastic drugs. All the samples with detectable amounts of cyclophosphamide or ifosfamide were from non-smokers; however, there was only one smoker in our study group. It was not possible to determine an effect of drug intake, in particular contraceptives, on the excretion of cyclophosphamide or ifosfamide.

\section{Discussion}

Despite standard safety precautions including a vertical laminar air flow safety cabinet and gloves, cyclophosphamide was detected in 12 of 31 urine samples, collected on days when cyclophosphamide was handled. Based on an excretion rate of $11.3 \%$ of the unmetabolised drug, $11.4 \mu \mathrm{g}$ cyclophosphamide $/ 24 \mathrm{~h}$ urine corresponds to an uptake of $101 \mu \mathrm{g}$, equivalent to $5 \mu \mathrm{l}$ of the original drug concentration. In one case an accidental spill of $1 \mathrm{ml}$ cyclophosphamide was reported by a nurse (personnel No 21) resulting in an incorporation of about $120 \mu \mathrm{g}$ cyclophosphamide. Ifosfamide was found in four of 21 analysed urine samples collected on days with ifosfamide manipulation. The calculated uptake of ifosfamide based on an excretion rate of $45 \%$ resulted in $20 \mu \mathrm{g}$ ifosfamide uptake or $0.5 \mu \mathrm{l}$ dissolved ifosfamide. It remains unknown, however, whether the excretion rate of the unchanged drug differs depending on the dose absorbed.

In two of 16 samples analysed after handling of the two drugs, both substances were detected; four samples contained only cyclophosphamide and one only ifosfamide.

Pertaining to the doses handled, the uptake of cyclophosphamide or ifosfamide was estimated to be approximately $0.0025 \%$ and $0.0004 \%$ respectively.

The amount of cyclophosphamide and ifosfamide excreted was of the same magnitude, but cyclophosphamide was found more often than ifosfamide. This is possibly due to the fact that cyclophosphamide is not as readily soluble in an aqueous solvent compared with ifosfamide, resulting in a longer handling time. Also, differences in the drug resorption and the higher number of cyclophosphamide preparations could have contributed to this finding. Neither of the substances was measured in urine from hospital personnel who collected urine one to two days after handling cyclophosphamide or ifosfamide. This finding is in agreement with the pharmacokinetic properties of both substances. ${ }^{10}$

The amount of cyclophosphamide or ifosfamide excreted did not relate to the dose or number of drug preparations on the day of 
urine collection or to the two days before urine collection. Similar findings have been reported. ${ }^{112}$ The number of ampoules used per preparation remains unknown. This could be of importance as the insertion of a needle into the ampoule to add fluid for dissolving the substance is a critical moment.

Furthermore, no significant correlation was seen between age, duration of exposure to cytostatic agents, drug intake, and the detection of cyclophosphamide or ifosfamide. Cyclophosphamide was found in the urine of only one male participant. The influence of sex on cyclophosphamide uptake, metabolism, and excretion has been discussed ${ }^{1213}$ but remains unclear due to the limited number of samples from male study participants.

Few investigations on biological monitoring of hospital personnel exposed to cytostatic drugs exist and the exposure is poorly quantified. Hirst et al reported on two nurses handling $0 \cdot 8-2.6 \mathrm{~g}$ cyclophosphamide without protective clothing. ${ }^{12} \mathrm{~A}$ maximum of $9 \mu \mathrm{g}$ cyclophosphamide was measured in urine. Despite regular safety precautions, Evelo et al and Sessink et al were able to measure up to $2.5 \mu \mathrm{g}$ cyclophosphamide in the urine of occupationally exposed personnel. ${ }^{11}{ }^{13}$ Pethran et al detected $3.35 \mu \mathrm{g}$ cyclophosphamide in the urine of a nurse who handled $500 \mathrm{mg}$ cyclophosphamide without glove protection. ${ }^{14}$ In comparison with our study group the dosage handled was considerably lower. We are not aware of any results on biological monitoring of workers exposed to ifosfamide.

Cytostatic drugs are resorbed transcutaneously and via inhalation of droplets. ${ }^{1214}$ In our investigation all the participants wore latex gloves although different fabrics with different glove thickness were used. The importance of the glove thickness in determining the permeability is sufficiently described. ${ }^{1516}$ Cyclophosphamide is classified as a slowly penetrating substance. ${ }^{1617}$ Differences between batches should also be considered. ${ }^{1618}$ To our knowledge no investigations have been performed on the permeability of gloves in the clinical situation with stretching of the material. Thus currently a routine glove change is recommended every 30 minutes, ${ }^{15} 18$ although this was not the habit in our study group. It is also possible that drug vials were handled without glove protection before mixing. This could be of importance as the contamination of ampoules was recently reported. ${ }^{11}$

The participants of our investigation handled cytostatic drugs exclusively in vertical laminar air flow safety cabinets. Although such cabinets contribute a major effect in reducing the contamination risk by aerosols, the protection provided can be disturbed by frequent personnel traffic, strong air drafts, and overloading of the cabinet surface. McDevitt et al were able to detect cyclophosphamide outside the biological safety cabinet face. ${ }^{19}$ Furthermore, great differences in the frequency of technical servicing was noticed in our study group.

Recent data point out widespread environmental contamination by cytostatic drugs in hospital pharmacies and wards. ${ }^{11} 1920$

A specific biological index for the evaluation of a potential health risk resulting from occupational exposure to antineoplastic agents is not available. The clinical evaluation of 16 of our study participants by physical examination, medical history, and blood tests revealed no abnormal findings related to the occupational exposure to antineoplastic drugs.

Studies concerning a possible hazard have given contradictory results. The determination of thioethers in urine and urine mutagenicity lack specificity, ${ }^{21}$ and the analysis of genotoxic variables such as chromosome aberrations and sister chromatid exchange in peripheral blood lymphocytes of occupationally exposed personnel differ considerably. ${ }^{22-26}$ Whereas some authors present data on a significant increase in chromosome breaks and chromosome aberrations, ${ }^{22} 24$ others did not find a significant difference in chromosome aberrations and sister chromatid exchange compared with non-exposed people. ${ }^{23}$ Few long term studies regarding miscarriages, congenital malformations, and malignant diseases of workers occupationally exposed to antineoplastic drugs exist. ${ }^{27-30}$ There is evidence of an increased rate of miscarriages ${ }^{29}$ and malformations. ${ }^{27} 28$ Negative results exist as well. ${ }^{30}$ Two studies on cancer morbidity of personnel handling antineoplastic drugs have not been able to quantify the exact risk ${ }^{3031}$ and longer follow up studies are needed.

Before discussing studies concerning the induction of second primary tumours after chemotherapy it needs to be emphasised that the doses of cyclophosphamide and ifosfamide absorbed by our study participants were $10^{-4}$ to $10^{-5}$ times smaller than the usual therapeutic doses that are given repeatedly intraveneously. Haas et al calculated a relative risk for acute leukaemia after treatment of ovarian or breast cancer with cyclophosphamide of 14.6 and $2 \cdot 7$, respectively. ${ }^{4}$ After an 11 year follow up of patients with rheumatoid arthritis treated with $50-150 \mathrm{mg}$ cyclophosphamide, the relative risk for the development of malignancy was determined to be $2 \cdot 3 .^{2}$ By comparison with these data, the potential risk after absorption of the observed trace amounts of cyclophosphamide and ifosfamide in our study group seems minute.

In summary, to date it remains difficult to estimate the potential health risk for hospital personnel involved in the preparation of cytostatic agents for patient therapy. Measurement of the excretion of these drugs in urine as an indicator of incorporation, is, however, a valuable index for the evaluation of the actual exposure. Thus the data presented here contribute greatly to the estimation of the potential hazards of personnel regularly handling antineoplastic drugs under standard safety precautions. 
1 International Agency for Research on Cancer. IARC monographs on the evaluation of the carcinogenic risk to monographs on the evaluation of the

2 Baker GL, Kahl LE, Zee BC, Stolzer BL, Agarwal AM, Medsger TA. Malignancy following treatment of rheumatoid arthritis with cyclophosphamide. $A m \mathcal{F} \mathrm{Med}$ 1987;83:1-9.

3 Greene MH, Boice JD, Greer BE, Blessing JA, Dembo AJ. Acute nonlymphocytic leukemia after therapy with alkylating agents for ovarian cancer. New Engl f Med 1982;307:1416-21.

4 Haas, JF, Kittelmann B, Mehnert WH, et al. Risk of leukaemia in ovarian tumour and breast cancer patients following treatment by cyclophosphamide. $\mathrm{Br} \mathcal{f}$ Cancer 1987;55:213-8.

5 Pedersen-Bjergaard J, Ersboll J, Sorensen HM, et al. Risk of acute nonlymphocytic leukemia and preleukemia in of acute nonlymphocytic leukemia and preleukemia in patients treated with cyclophosphamide for Non-
Hodgkin's disease. Ann Intern Med 1985;103:195-200.

6 Valanis B, Vollmer WM, Labuhn K, Glass A, Corelle C. Antineoplastic drug handling protection after OSHA guidelines. $\mathcal{F}$ Occup Med 1992;34:149-55.

7 Bürckmann R. Belastungen von Krankenhauspflegepersonal durch Zubereitung des Zytostatikums Cyclophosphamid [diploma thesis]. Munich: Ludwig-Maximilians Universität, 1991.

8 Jardine I, Fenselau C, Appler M, Kan MN, Brundrett RB, Colvin M. Quantitation by gas chromatography-chemical ionization mass spectometry of cyclophosphamide, phosphoramide mustard, and nornitrogen mustard in phosphoramide mustard, and nornitrogen mustard in the plasma and urine of patients receiving

9 Martino R, Martino-Malet MC, Armand JP, Forni M Poentialites de la RMN du fluor-19 et du phosphore-31 pour l'etude du metabolisme et de la pharmacocinetique d'agents antitumoraux fluores ou phosphores. Bull Cancer (Paris) 1989;76:859-61.

10 Colvin M. The comparative pharmacology of cyclophosphamide and ifosfamide. Seminars in Oncol 1982;9:2-7.

11 Sessink PJM, Boer KA, Scheefhals APH, Anzion RBM, Boss RP. Occupational exposure to antineoplastic agents at several departments in a hospital. Int Arch agents at several departments in a hos

12 Hirst M, Tse S, Mills DG, Levin L. Occupational exposure to cyclophosphamide. Lancet 1984;i:186-8.

13 Evelo CTA, Bos RP, Peters JGP, Henderson P Th. Urinary cyclophosphamide assay as a method for biological monitoring of occupational exposure to cyclophosphamide. Int Arch Occup Environ Health 1986;58: 151-5.

14 Pethran A, Römmelt H, Bürckmann R. Bestimmung von Cyclophosphamid und Thioethern im Urin von Krankenschwestern unter Berücksichtigung unterschiedlicher Zubereitung der Zytostazita. Verhandl $D t$ Ges Arbeitsmed 1992:477-81.

15 Laidlaw JL, Connor TH, Theiss JC, Anderson RA, Matney TS. Permeability of latex and polyvinyl chloride Matney TS. Permeability of latex and polyvinyl chloride
gloves to 20 antineoplastic drugs. Am 7 Hosp Pharm gloves to 20 antine

16 Slevin ML, Ang LM, Johnston A, Turner P. The efficiency of protective gloves used in the handling of cytostatic drugs. Cancer Chemother Pharmacol 1984;12: $151-3$.

17 Mader RM, Rizovski B, Steger GG, Moser K, Rainer H, Dittrich C. Permeability of latex membranes to anticancer drugs. International fournal of Pharmaceutics cancer drugs.

18 Stoikes, ME, Carlson JD, Farris FF, Walker PR Permeability of latex and polyvinylchloride gloves to fluorouracil and methotrexate. Am ₹ Hosp Pharm 1987; 44:1341-6.

19 McDevitt JJ, Lees PSJ, McDiarmid MA. Exposure of hospital pharmacists and nurses to antineoplastic agents. F Occup Med 1993;35:57-60.

20 Pyy L, Sorsa M, Hakala E. Ambient monitoring of cyclophosphamide in manufacture and hospitals. Am Ind Hyg Assac F 1988;49:314-7.

21 Jagun O, Ryan M, Waldron HA. Urinary thioether excretion in nurses handling cytostatic drugs. Lancet 1982;ii:443-4.

22 Nikula E, Kiviniitty K, Leisti J, Taskinen PJ. Chromosome aberrations in lymphocytes of nurses handling cytostatic agents. Scand $\mathscr{f}$ Work Environ Health 1984; 10:71-4.

23 Oestreicher U, Stephan G, Glatzel M. Chromosome and SCE analysis in peripheral lymphocytes of persons occupationally exposed to cytostatic drugs handled with and without use of safety covers. Mutat Res 1990;242: 271-7.

24 Thiringer G, Granung G, Holmen A, Högstedt B Järvholm B, Jönssen D, et al. Comparison of methods for the biomonitoring of nurses handling antifor the biomonitoring of nurses handling anttumor

25 Sorsa M, Pyy L, Salomaa S, Nylund L, Yager JW. Biological and environmental monitoring of occupational exposure to cyclophosphamide in industry and hospitals. Mutat Res 1988;204:465-79.

26 Stücker I, Caillard JF, Collin R, Gout M, Poyen D, Hemon D. Risk of spontaneous abortion among nurses handling antineoplastic drugs. Scand $f$ Work Environ Health 1990;16:102-7.

27 Hemminki $K$, Kyyrönen $P$, Lindbohm ML Spontaneous abortions and malformations in the offspring of nurses exposed to anaesthetic gases, cytostatic drugs, and other exposed to anaesthetic gases, cytostatic drugs, and other
potential hazards in hospitals, based on registered inforpotential hazards in hospitals, based on registered information of

28 McDonald AD, McDonald JC, Armstrong B, et al. Congenital defects and work in pregnancy. Br f Ind Med 1988;45:581-8.

29 Selevan SG, Lindbohm ML, Hornung RW, Hemminki K. A study of occupational exposure to antineoplastic drugs and fetal loss in nurses. New Engl $\mathcal{F}$ Med 1985; 313:1173-8.

30 Skov T, Maarup B, Olsen J, Rorth M, Winthereik H, Lynge $\mathrm{E}$. Leukemia and reproductive outcome among nurses handling antineoplastic drugs. Br $\mathcal{F}$ Ind Med 1992;49:855-61.

31 Skov T, Lynge E, Maarup $B$, Olsen J, Rorth $M$, Winthereik H. Risks for physicians handling antineoplastic drugs. Lancet 1990;336:1446. 